\title{
A Pilot study to assess the safety of Rasamanikya (An Arsenical formulation) in healthy volunteers
}

\author{
Research Article
}

\section{Nilima N Wadnerwar1*, Abhay H Patkar ${ }^{2}$}

\section{Associate Professor, Department of Agadtantra, Mahatma Gandhi Ayurved College, Hospital \& Research} Centre, Salod (H), Datta Meghe Institute of Medical Sciences (DU), Wardha, Maharashtra.

2. Professor, Department of Agadtantra, A.S.S. Ayurved Mahavidyalaya, M.U.H.S. Nashik; Adjacent Faculty, Department of Agadtantra, Mahatma Gandhi Ayurved College, Hospital \& Research Centre, Salod (Hirapur), Datta Meghe Institute of Medical Sciences (Deemed to be University), Wardha-442001, Maharashtra, India.

\begin{abstract}
Backround: Ayurvedic medicines are alleged to be one of the sources of heavy metal toxicity. Hence, it has become necessary to prove their safety on the scientific base with appropriate evidences. Methodology: A pilot study was conducted after the preclinical safety evaluation of Rasamanikya, an arsenical formulation in Ayurveda. Ten healthy volunteers were administered Rasamanikya $125 \mathrm{mg}$ twice a day for fifteen consecutive days. Heavy metal estimation in blood was conducted before intervention and at the end of intervention. Student's paired t test was applied at 5\% level of significance. Result: Out of nine heavy metals, only Arsenic in blood was increased significantly in all the ten volunteers without any signs of clinical toxicity. Conclusion: The drug was found to be safe as evidenced in the previous preclinical study.
\end{abstract}

Key Words: Heavy metal toxicity, Rasamanikya, Safety, Preclinical study.

\section{Introduction}

Rasamanikya is an Arsenical formulation which is very popular and drug of choice in Ayurveda for various types of skin and blood disorders as well as infection. It is prepared from purified Haratala (Orpiment) which is Arsenic trisulphide.

As Arsenic is a heavy metal, there are concerns about the limit of these heavy metals in the formulations of Ayurveda. Herbs, metals and minerals or in combination with herbs as herbomineral formulations are described in the management of diseases in classical texts of Ayurveda. Single and multi drug herbal formulations are used according to their pharmacological properties, potency and effect since ancient period. After that minerals were used to add in these herbal formulations to increase the potency of the herbal drugs which are known as herbo-mineral drugs. Likewise, these mineral drugs were used as main drug along with other minerals known as Rasakalpa (Mineral formulations). Some of these minerals which are considered as heavy metals are known to have some toxic effects. But the use of herbal and mineral toxic drugs is already mentioned since period of Veda and Samhita (Treatise of Ayurved). These toxic drugs are used after proper purification and or incineration

\section{* Corresponding Author:}

\section{Nilima N Wadnerwar}

Associate Professor, Department of Agadtantra, Mahatma Gandhi Ayurved College, Hospital \& Research Centre, Salod (H), Datta Meghe Institute of Medical Sciences (DU), Wardha, Maharashtra, India. Email Id: dr.nilima_wadnerwar@rediffmail.com methods to prepare formulation for the treatment. This practice was adopted to increase the potency of the formulation in smaller dose and to provide the quick relief. The minerals which are commonly used in Ayurveda are Parada (Mercury), Somala (Arsenic trioxide), Haratala (Arsenic trisulphide), Manashila (Arsenic bisulphide), Naga (Lead), Tamra (Copper), Vanga (Zinc), Loha (Iron) etc.

Most of the heavy metals are used to prepare formulations only after purification and incineration methods of the metal according to their classical references. Moreover, herbomineral drugs are advised to prescribe for short duration. If they are needed for longer duration, they should be prescribed after a washout period. But if these methods are not followed properly according to the classical references and if they are consumed continuously without physician's advice, the formulation may cause hazardous effect immediately or after some period depending upon the dose and route of administration of the drug.

In ancient times, physicians were used to prepare these formulations on small scale according to the classical references. But in current scenario due to commercialization, modern techniques and advanced equipments are used to prepare these formulations on large scale. Due to this, quality control of these formulations is a big question. Moreover, the main concern is the level of heavy metals present in these formulations due to which the formulations of Ayurveda are targeted for their toxicity though they are efficacious $(1,2,3,4,5)$. To control the limits of heavy metal in formulations of Ayurveda, Central Council of Indian Medicine (CCIM) has revised permissible limits of heavy metals in Ayurveda, Siddha and Unani 
Medicines. Such permissible or non permissible limit is not described for the formulations containing only minerals. Hence to assess the chronic toxicity of Ayurvedic formulation, the author has selected Rasamanikya which is an Arsenic formulation and conducted Arsenic estimation of three different market preparations of Rasamanikya. (6) Rasamanikya containing highest percentage of Arsenic was subjected to acute and chronic toxicity study in her previous research project. LD 50 of Rasamanikya was found to be more than $2000 \mathrm{mg} / \mathrm{kg}$ and the drug was found to be safe in Albino rats in 90 days study.(7) To confirm these results in human beings, this pilot study was conducted to assess the safety of Rasamanikya.

\section{Material and methods}

With reference to previous chronic toxicity study of Rasamanikya conducted in Albino Wistar rats (7), to confirm the results of toxicity study, a pilot study was conducted. Clinically healthy ten volunteers of age 21 years were selected and consent was taken after due consultation. The volunteers were informed to avoid sea food, non vegetarian diet and other medicines seven days prior to intervention and during the intervention. Rasamanikya sample procured from market and which was proved to be safe in Albino rats in previous study was administered orally in a dose $125 \mathrm{mg}$ twice a day after meals for 15 days under the supervision of the physician.

Heavy metal estimation in blood was conducted before and after the consumption of Rasamanikya. For this, blood sample was collected in EDTA tube. Blood metal estimation was conducted at Thyrocare Technologies Limited, Navi Mumbai. Inductively Coupled Plasma Mass Spectroscopy (ICP- MS) method was used to estimate heavy metals in blood with highly sensitive instrument named iCAPQc ICP-MS. The values were expressed in $\mu \mathrm{g} / \mathrm{l}$.

The follow up was taken at $7^{\text {th }}$ and $16^{\text {th }}$ day during intervention and every month after the intervention for six months.

The results were presented as Mean \pm Standard Error (SEM) of means. Statistical comparisons were performed by student's paired $t$ test by using Sigma stat software (version 3.1) to determine the significant difference at $p<0.05$ (level of significance).

\section{Observations and Result}

Table No.1: Effect of Rasamanikya on Blood Arsenic Level $(\mu \mathrm{g} / \mathrm{l})$

\begin{tabular}{|c|c|c|c|c|c|}
$\begin{array}{c}\text { Blood Arsenic } \\
\text { Level }\end{array}$ & Mean & $\begin{array}{c}\text { Std } \\
\text { Dev }\end{array}$ & SEM & $\begin{array}{c}\mathbf{t} \\
\text { value }\end{array}$ & p value \\
\hline $\begin{array}{c}\text { Before treatment } \\
\text { After treatment }\end{array}$ & 0.714 & 0.278 & 0.0879 & -9.364 & $\mathrm{p}<0.00$ \\
\hline
\end{tabular}

The difference in Blood Arsenic Level was statistically significant $(p<0.001)$. The Arsenic levels were increased in all the ten healthy individuals after the consumption of Rasamanikya for fifteen days. But there were no clinical signs of Arsenic toxicity at these levels during or after intervention. The volunteers were not having any signs of Arsenic toxicity even after follow up upto six months after invention.
Table No.2: Effect of Rasamanikya on Blood

Cadmium Level $(\mu \mathrm{g} / \mathrm{l})$

\begin{tabular}{|c|c|c|c|c|c|}
$\begin{array}{c}\text { Blood Cadmium } \\
\text { Level }\end{array}$ & Mean & $\begin{array}{c}\text { Std } \\
\text { Dev }\end{array}$ & SEM & $\begin{array}{c}\text { t } \\
\text { value }\end{array}$ & $\begin{array}{c}\mathbf{p} \\
\text { value }\end{array}$ \\
\hline Before treatment & 0.182 & 0.0993 & 0.0314 & -3.766 & $\begin{array}{c}\mathrm{p}= \\
0.004\end{array}$ \\
\hline After treatment & 0.303 & 0.144 & 0.0455 & & \\
\hline
\end{tabular}

The difference in Blood Cadmium Level was statistically significant $(\mathrm{p}=0.004)$ but the observed values were within normal limit in all the ten healthy individuals.

Table No.3: Effect of Rasamanikya on Blood Mercury Level $(\mu \mathrm{g} / \mathrm{l})$

\begin{tabular}{|c|c|c|c|c|c|}
\hline $\begin{array}{c}\text { Blood Mercury } \\
\text { Level }\end{array}$ & Mean & $\begin{array}{l}\text { Std } \\
\text { Dev }\end{array}$ & SEM & $\begin{array}{c}\text { t } \\
\text { value }\end{array}$ & p value \\
\hline Before treatment & 0.426 & 0.394 & 0.124 & \multirow{2}{*}{-0.324} & $p=$ \\
\hline After treatment & 0.448 & 0.426 & 0.135 & & 0.753 \\
\hline
\end{tabular}

Table No.5: Effect of Rasamanikya on Blood Lead Level $(\mu \mathrm{g} / \mathrm{l})$

\begin{tabular}{|c|c|c|c|c|c|}
\hline $\begin{array}{c}\text { Blood Lead } \\
\text { Level }\end{array}$ & Mean & $\begin{array}{l}\text { Std } \\
\text { Dev }\end{array}$ & $\begin{array}{l}\text { SE } \\
\text { M }\end{array}$ & $\begin{array}{c}t \\
\text { value }\end{array}$ & $\underset{\text { value }}{\mathbf{p}}$ \\
\hline Before & & 14.674 & 4.640 & 0.423 & \\
\hline
\end{tabular}

The difference in Blood mercury $(\mathrm{p}=0.753)$ and lead $(\mathrm{p}=0.682)$ level was statistically insignificant and the observed values were within normal limit in all the ten healthy individuals. However, the other heavy metals in blood like Chromium, Barium, Cobalt, Caesium and Selenium were within normal limit.

\section{Discussion}

The prevalence of heavy metal toxicity has increased since seven decades due to presence of exceeding limits of heavy metals in the water, food and other industrial sources. Now the formulations of Ayurveda are also dragged in the allegations to contain the heavy metals in exceeding limits. Formulations of Ayurveda mainly contain Mercury, Arsenic, Lead and Copper as heavy metals. They are processed systematically not to cause any harm to the human beings. In the current trend, physician do not prepare these formulations due to complex and time consuming methods of preparation and as they are readily available in the market. $90 \%$ patients consume market preparations. But the commercialization in the pharmaceutical world has brought with many challenges about safe use of Ayurvedic medicines and need of standardization. The possibility of contamination of raw drug with other toxic metals and minerals could not be neglected. This contamination may be natural as most of the heavy metals are found in the Earth's crust or the contamination may be acquired due to environmental contamination due to widespread use of these heavy metals.

After the review of published articles regarding heavy metal content in AYUSH medicines and cases of heavy metal toxicity, some observations were noted that the AYUSH medicines are available at grocery shops and food stores in foreign countries. Dietary supplements in AYUSH sold in foreign countries are not regulated on safety and efficacy standards $(8,9)$. 
AYUSH medicines are purchased through internet and consumed without the prescription of physician when it is strictly recommended that medicines containing toxic drugs should be consumed as per the directions of physician. Patients purchasing AYUSH herbomineral medicine through internet and consuming them continuously for longer duration without the supervision of physician are more prone to cause heavy metal toxicity. The other causes of heavy metal contamination and their effect on Ayurvedic medicine are not considered anywhere.

Though chronic Arsenic poisoning following Ayurvedic medication was reported in cases (10), in previous preclinical study (7) as well as in present clinical pilot study, Rasamanikya is found to be safe when it is consumed in proper dose for proper duration and under the supervision of physician. Apart from this, some studies have proven safety and efficacy of Ayurvedic formulations as well as metallic preparations even in complicated diseases $(11,12,13,14)$. In similar way, other herbal, mineral and herbomineral formulations in Ayurveda can be studied for their safety.

\section{Conclusion}

Rasamanikya, the Arsenical formulation and the potential medicine in Ayurveda for skin diseases and infections is found safe not only in preclinical but also in clinical study. It can be used safely in therapeutic dose for prescribed duration under the supervision.

\section{References}

1. Hore P, Ahmed M, Ehrlich J, Steffen L, Sedlar S, Johnson PC et al. Lead poisoning in pregnant women who used Ayurvedic Medications from India-New York city, 2011-2012, Centre for disease control and prevention (Morbidity and mortality weekly report), August, 2012;61(33); 641-657.

2. Devarbhavi H. Ayurvedic and herbal medicine induced liver injury: It is time to wake and take notice. Indian J. Gastroenterol. January, 2018; 37(1);5-7.

3. Dalal KK, Holdbrook T, Peikin SR. Ayurvedic drug induced liver injury. World J. Hepatol November,2017; 9(31);1205-1209.

4. Beniwal P, Gaur N, Singh SK, Raveendran N, Malhotra V. How harmful can herbal remedies be? A case of severe acute tubule-interstitial nephritis. Indian J. Nephrol. November,2017; 27(6);459-461.
5. Creemers L, Van den Driessche M, Moens M, Van Olmen A, Verschaeren J, T'Syen M, et al. Safety of Alternative Medicines Reconsidered: Lead-Induced Anaemia Caused By An Indian Ayurvedic Formulation. J. Acta Clinica Belgica. January,2007; 63(1); 548-551.

6. Wadnerwar NN, Patkar AH, Mogal B. Analytical study of three market preparations of Rasamanikya, with special reference to its metallic Arsenic concentration. MUHS Health Science Review. December, 2018;1(2):29-36.

7. Wadnerwar NN, Patkar AH. Chronic toxicity evaluation of Ayurvedic Arsenical formulation Rasamanikya with special reference to heavy metal toxicity. International journal of Pharmaceutical Research. January, 2020;12(1); 889-898.

8. Saper RB, Phillips RS, Sehgal A, Khouri N, Davis RB, Paquin $J$ et al. Lead, Mercury and Arsenic in US -Indian Manufactured Ayurvedic Medicines sold via the internet. JAMA. August, 2008; 300(8);915-923.

9. Saper RB, Kales SN, Paquin J, Burns MJ, Eisenberg DM, Davis RB et al. Heavy metal content of Ayurvedic herbal medicine products. JAMA. December,2004; 292(23);2868-2873.

10. Pinto B, Goyal P, Flora SJS, Gill KD, Singh S. Chronic Arsenic Poisoning Following Ayurvedic Medication. J. Med. Toxicol. December,2014;10(4);395-398.

11. Ambhore KP, Wajpeyi SD. Comparative study of Lodhradi Lepa with and without Arogyavardhini Vati in the management of Yuvanpidika. Journal of Indian System of Medicine. January, 2020; 8(1);21-28.

12. Gokarn R, Rajput DS, Bedarkar P, Galib, Patgiri BJ, Prajapati PK. Present trends of researches in Rasashastra emphasizing safety of certain metallic preparations - A brief review. J Indian Sys Medicine. December, 2014:2(4); 206-209.

13. Wajpeyi SM. Role of Ayurveda in the Management of Guillain-Barré Syndrome. International Journal of Ayurvedic Medicine. December, 2018; 9(4); 288-292.

14. Zanwar AC, Wajpeyi SM. Management of Hepatitis B (Carrier stage) through Ayurved-A Case report. International Journal of Ayurvedic Medicine. December, 2019;10(4);342-344. 